\title{
A Tribute to John Roger Bider, 1932-2013
}

\author{
Rodger D. Titman*, G. Jean Doucet, Gregory Weil, and David M. Bird
}

Department of Natural Resource Sciences, Macdonald Campus, McGill University, 21,111 Lakeshore Road, Ste-Anne-de-
Bellevue, Quebec H9X 3V9 Canada
*Corresponding author; email: rodger.titman@mcgill.ca

Titman, Rodger D., G. Jean Doucet, Gregory Weil, and David M. Bird. 2013. A tribute to John Roger Bider, 1932-2013. Canadian Field-Naturalist 127(4): 358-365.

John Roger Bider was born on 23 November 1932, the second son of Frédérick André Bider (who had emigrated from Switzerland) and Catherine Corcoran. He grew up in Valois, a district of Pointe-Claire on the island of Montréal, Quebec, an area that was considered to be rural at the time. His home was within walking distance of Lac St. Louis, at the convergence of the Ottawa River and the St. Lawrence River. Nearby and draining into the lake was a fabulous ditch, where Roger had his first encounters with Northern Pike (Esox lucius), with frogs, and with Muskrat (Ondatra zibethicus) tracks in the mud.

He developed interests in natural history, nurtured by his mother, and mechanical abilities, fostered by his father, who was involved in the construction industry. At the age of 13 he spent a summer on a progressive dairy farm. Over the next two summers, Roger was engaged in demolition and construction. He graduated from Macdonald High School in 1950. He spent two summers in northern Ontario involved in forest entomology and then another two summers in Lachine at the Quebec Fish and Game Muskellunge (Esox masquinongy) hatchery on Lac St. Louis. He was involved in the release of hatchery-reared muskies into Lac Tremblant.

Following two years as a student in the Faculty of Forestry at the University of New Brunswick, Roger operated a trout hatchery and lake management company for a couple of years at Lac Carré in the Laurentians, north of Montreal. His hatchery stock was delivered by truck or float plane to fishing clubs and outfitters all over the Laurentians. With these activities Roger developed a great love of the Laurentians, where he kept returning for the rest of his life. He eventually transferred to the Université de Montréal to complete an undergraduate degree and graduated with honours in biology in 1956. In that same year he married Marjorie Jean Morphew. Together they had six children: Timothy, Steven, Donna, Keith, Jeanette, and Marc.

Continuing at the Université de Montréal, he studied habitat use and animal activity by tracking Snowshoe Hares (Lepus americanus) for a master's degree under the supervision of Paul Pirlot, received in 1959. He enrolled in a Ph.D. program later that year at the University of Texas, basing his fieldwork at the Welder Wildlife Refuge in Sinton, Texas.

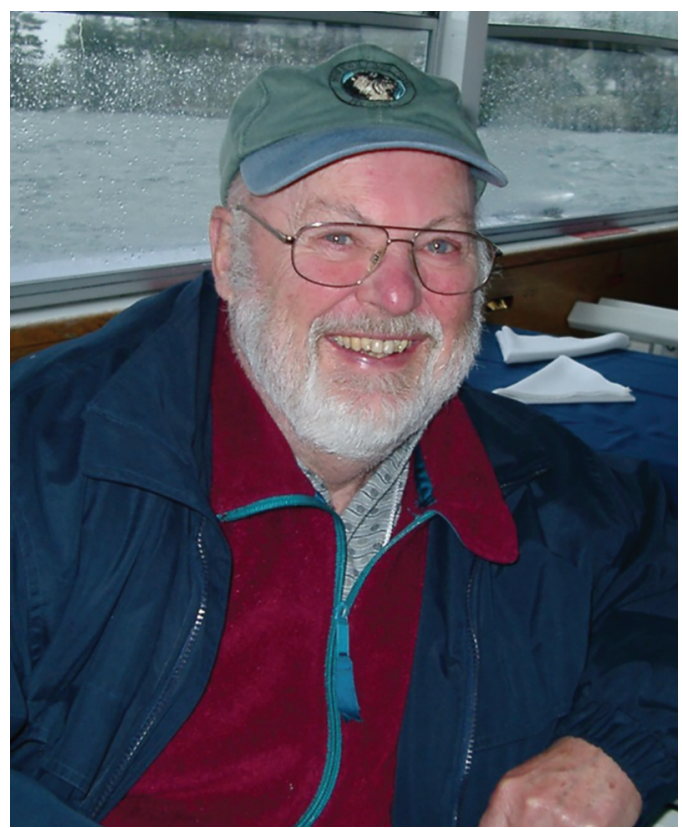

FIgURE 1. Roger Bider during a cruise on the St. Lawrence River, 1990. Photo: D. Bird.

Roger returned to Montreal in 1961 and taught general biology and invertebrate zoology at Loyola College. He then resumed his quest for a Ph.D., but this time at the Université de Montréal. While completing his Ph.D., also under Paul Pirlot, he replaced Jim Mosimann, who had accepted a position in the United States. Roger taught advanced animal ecology and introduced sand-tracking to the students. In doing so, Roger essentially introduced terrestrial animal ecology to an institution where the emphasis had been on aquatics. Although he was at the Université de Montréal for only a short period, testimonials indicate that Roger's unassuming approach and solid knowledge were much appreciated. Some of his students remained connected to him for more than 50 years, especially in relation to northern hydroelectric development projects (James Bay and the proposed Grande rivière de la baleine (Great Whale) project). He completed his Ph.D. in 1966. His innovative use of the sand-tracking technique, begun in coastal 
Texas, led to research on animal behaviour and community ecology that he would pursue over the next 20 years with a series of graduate students.

Roger was appointed Assistant Professor of Wildlife Biology in the Department of Woodlot Management, Faculty of Agriculture, at Macdonald College, McGill University, Sainte-Anne-de-Bellevue, Île de Montréal, Quebec, in 1965. He remained at Macdonald College until he retired in 1996, progressing quickly through the ranks to Associate Professor in 1969 and then to Full Professor in 1975. He served as Chairman of the Department of Woodlot Management from 1970 to 1972 and, following the merger of Woodlot Management and Soil Science in 1973, served as Chairman of the Department of Renewable Resources from 1977 to 1983.

Roger's students at Loyola, the Université de Montréal, and Macdonald College quickly became aware that the conventional lecture was not his favoured platform. In those days, class sizes were much smaller and Roger preferred an informal atmosphere. At times, he would simply sit on a desk wearing his terry-cloth Tshirt and tell anecdotes about his experiences in the field. He was a master at keeping students interested while conveying fish and wildlife management concepts in a laid-back, conversational manner. Students developed great respect for him, operating as an equal; he was akin to a lovable older hockey coach.

One of us (GJD) attended those early classes and recalls the time when Roger indicated he would be travelling to Newfoundland for a seminar. He was asked if he could bring back a bottle of Screech. This was not a request one would have made of other teachers. At the first lecture following his return, there was a sense that he had acquiesced to the request, but the class had to wait to the end to find out. He was special to his students, and lifetime bonds were formed. It was in the field, as a true naturalist, that he excelled. Crossing an old field with Roger was a class and a lab session all rolled into one, and, if you were attentive, you arrived at the next fence a better naturalist.

He developed the wildlife biology program at McGill University, and the program flourishes today (under another rubric) and attracts significant numbers of students. He taught courses in vertebrate anatomy, natural history, principles of ecology, renewable resources, conservation, and fisheries and wildlife management. One very popular course he initiated in 1975 was Desert Ecology, drawing from his experience and early education in Texas and Arizona. There was keen competition to enroll in this field course (numbers were limited), which visited deserts in the southern United States for an intense three weeks of camping and exploring these most intriguing habitats.

Roger's study, Animal Activity in Uncontrolled Terrestrial Communities as Determined by a Sand Transect Technique (published in 1968), was a seminal work. This research and that of graduate students, most- ly conducted at Lac Carré using sand-tracking, had a significant impact on the study of animal activity and behavior and ultimately wildlife management. He supervised 42 graduate students through to completion (5 $\mathrm{Ph} . \mathrm{D}$. degrees and 37 master's degrees). All together, 22 of the 42 were involved in sand-tracking.

During Roger's research career, the first major emphasis was a consideration of various factors that influenced daily activity in a wide variety of animals, ranging from insects through snakes, frogs, turtles, and small mammals to large carnivores. Later he was involved in an intensive study of Painted Turtles (Chrysemys picta) and other local turtle species. In response to a request from the federal Ministry of Agriculture and local farmers, Roger and his research group conducted studies to mitigate the impacts of pest Red-winged Blackbirds (Agelaius phoeniceus) on corn crops. Pat Weatherhead, then completing a Ph.D. at Queen's University in Kingston, Ontario, was engaged to oversee this effort, in which a notable number of graduate students were involved and which produced publications from 1977 to 1985 .

In 1973, Roger shared a vision with a falconer from the United Kingdom of breeding Peregrine Falcons (Falco peregrinus) in captivity, with the objective of releasing the young into the wild to restore their numbers. Peregrine Falcons had become endangered due to eggshell thinning caused by the widespread use of organochlorines such as DDT. Roger brought together and chaired a group of McGill University professors from both the downtown Montreal campus and the Sainte-Anne-de-Bellevue campus with expertise in avian biology and poultry production to create the Macdonald Raptor Research Centre (MRRC), later known as the Avian Science and Conservation Centre (ASCC). More than 50 Peregrine Falcons were released on the Île de Montréal.

Besides its focus on the Peregrine Falcon, the Macdonald Raptor Research Centre became involved in the rehabilitation of sick, injured, and orphaned raptors and a program to educate the public about the plight of birds of prey in general. During the first year of the Centre's existence, Roger took on DMB, a master's candidate, to develop artificial insemination procedures for Peregrine Falcons in collaboration with two animal scientists. This eventually culminated in the production of the world's first Peregrine Falcon bred by artificial insemination and, later, the first Peregrine Falcon produced from frozen and thawed semen. DMB not only completed his Ph.D. at the Centre, but also went on to become its first director, in 1978. By 2012, the Avian Science and Conservation Centre had worked with close to 70 graduate students and produced over 200 papers in refereed scientific journals. The raptor rehabilitation program was transferred to the Faculté de medicine vétérinaire at the Université de Montréal, where the program developed into one of Canada's foremost rehabilitation and public education centres for 
birds of prey. Subsequently, in the 1980s, the public education program was relocated to Roger's pet project- the Ecomuseum.

Other graduate students contributed significantly to Roger Bider's legacy. His former graduate students have become professors, as well as scientists with the Canadian Wildlife Service (Environment Canada), Fisheries and Oceans Canada, the Quebec ministries dealing with fisheries and wildlife, the Royal Ontario Museum, Hydro-Québec, Ontario Hydro, the Ontario Ministry of Natural Resources, Ducks Unlimited, the Nature Conservancy of Canada, Makivik Corporation, the Toronto Zoo, and consulting companies dealing with environmental impact (André Marsan et Associés, Lavalin, Stantec).

Somewhat peripheral to his academic responsibilities, Roger was engaged in a variety of environmental causes. In the early 1970s, he formed Public Awareness of Wildlife (PAW), a program which employed students using hand-reared wildlife to make people more aware of their natural environment. Around this time, the Quebec government established a bounty to kill Gray Wolves (Canis lupus), which were blamed for reducing White-tailed Deer (Odocoileus virginianus) populations in the province. Involving students and interested conservationists, PAW evolved into Public Awareness of Wolves, which was instrumental in convincing the Quebec wildlife branch (Ministère du Loisir, de la Chasse et de la Pêche du Québec) to repeal the bounty program.

From 1967 to 1969, Roger had a research contract with the Forestry Service, then part of the federal Department of Fisheries and Forestry and now part of Natural Resources Canada, to study the ecology of the Cinereus (Masked) Shrew (Sorex cinereus), which had been introduced onto the island of Newfoundland from New Brunswick to control the Larch Sawfly (Pristiphora erichsonii). At the time, Cinereus Shrews were advancing at a rate of $21 \mathrm{~km} /$ year across the island. Raymond Sarrazin, a graduate student, was field manager for the project.

Beginning in 1968, together with Douglas Pimlott and C. J. Kerswill, Roger was involved in the preparation of a background study for the Science Council of Canada examining scientific activities related to fisheries and wildlife resources. This gave him "incredible insights" (his words) into the sociological and economic aspects of wildlife management that influenced his teaching and approach to wildlife management.

Roger conducted environmental impact studies for La Grande hydro development near James Bay (Société d'Énergie de la Baie James), development of the Mirabel Airport, and the proposed Great Whale hydroelectric project. He advised the governments of Burundi, Burkina Faso, and Haiti concerning wildlife management issues. He sat on the Quebec Conseil consultatif de l'environnement in its various names for three three-year terms between 1973 and 1990. $\mathrm{He}$ also advised different federal and provincial gov- ernment agencies about vertebrate pest management between 1986 and 1997.

Roger always sought different perspectives on the natural world he loved to study and reveal to others. He enjoyed seeing a given habitat from above. This was likely influenced by the aerial surveys he had done to locate American Beaver (Castor canadensis), Caribou (Rangifer tarandus), and other large ungulates during his environmental impact studies. One interesting quest for this different perspective involved his learning to fly a single-engine plane. He took the courses, learned to fly, and then was failed on a technicality when he attempted to land the plane at the closed airport near Lachute during his final test flight. That was it for him as a pilot.

Ultimately a major preoccupation was his development of an ecological park. Roger had already taken students on a one-week wildlife management field trip each year to Lac Carré, and as part of the Desert Ecology course he had taken students into the field for three weeks every two years to learn about deserts. Associated with the desert trips was a visit to the ArizonaSonora Desert Museum in Tucson, which Roger had visited for the first time in 1965, when he received an award from the U.S. National Science Foundation to study desert biology at Arizona State University. This living museum impressed Roger with its innovative, bold, and interactive approach to interpreting the Sonoran Desert. It also provided a model for Roger's thinking about public education.

Meanwhile, Roger became part of a local group that was developing a project in Senneville, Quebec, called Parc écologique. The group's original ambition of incorporating ecological agriculture and wildlife interpretation was not realized but, in the process, Roger became aware of a tract of land at McGill University that was being used as a dump site. In this land, he saw the possibilities of his nature interpretation park. In 1981, a non-profit corporation, the St. Lawrence Valley Natural History Society, was formed to develop such a facility. In 1984, clean-up of the landfill and dump site over what was formerly a beautiful marsh was begun. By 1988, after Roger had been very actively involved in site clearing, negotiation with McGill, fundraising, and design and construction of buildings and enclosures, the Ecomuseum opened its doors to the public. From that point until he retired from McGill University, Roger spent every spare moment at or thinking about the Ecomuseum.

Roger never tired of introducing people to the juicy facts of life in the natural world. He loved the animals that were the key ingredients of his zoo. In this era, little money was available, and everything was done as frugally as possible. It was amazing what Roger accomplished under the circumstances. Roger readily acknowledged the significant role volunteers played in the development of the Ecomuseum. 
Retirement in 1996 allowed Roger to devote all of his time to the Ecomuseum. While his wife, Marge, had to spend her time there as well just to see him, she certainly gave him tremendous support throughout. Roger was the director until 2005 and only in the couple of years prior to relinquishing this responsibility did he finally spend some time elsewhere. First Stéphane Poulin and then David Rodrigue were at his side until David Rodrigue became the executive director.

Roger was honored by the Société Provancher d'histoire naturelle du Canada with its award as "Un Gens d'action" in 1994 for establishing the Ecomuseum, also by the Fondation de la faune du Québec, by Bird Protection Quebec with the Education Award in 2008, and by the Ecomuseum in 2012, when its spectacular new aviary was named in his honour.

Through the Ecomuseum, Roger coordinated the collection of distribution data to produce Quebec's first atlas of reptiles and amphibians, in 1988, coauthored by Sylvie Matte. This valuable conservation resource is still being updated annually by Ecomuseum staff supported by the provincial government.

It was a delight walking in the woods with Roger Bider. He enjoyed recounting how plants and animals of the local community interacted with each other. He knew the different species of diverse taxonomic groups that comprised the community. He was an "old school" field naturalist, difficult to find these days among modern specialist biologists that often do not see the forest for the trees. Roger loved to explore and reveal the links that bring the diverse units together. He was at his best on field trips with his students, bringing the principles of ecology to life in real time. Whether it was in a pond, a stream, a meadow, a forest, or a desert, he was the consummate naturalist and teacher.

Roger was a keen observer of human nature. He could seem removed in a group setting, but he was in fact taking it all in. He rarely spoke about himself or revealed his feelings, but he enjoyed meeting new people from different walks of life to learn about their past and connections. He had an uncanny way of finding and attracting people who could advise him and support his vision, recognizing that their particular strengths and expertise could complement his own. In a relaxed set- ting, Roger could play, be mischievous, and enjoy the odd prank.

Roger and Marge were keen baseball fans, supporting the Montreal Expos, particularly when they played at Jarry Park, and would have been season-ticket holders had smoking in the stands been prohibited at the time.

Roger was an innovator. Whenever he hit a roadblock, he would "drive" around it (or sometimes through it), finding alternatives to the original course of action to reach his objective. He was very adaptable and unconfined by practice and tradition. Once he had brought a project to fruition, he would move on to what he considered the next exciting challenge.

Roger died peacefully 29 April 2013 after a sevenyear battle with Parkinson's disease. During that time, especially in the early stages, he did not remain idle. He remained interested in wildlife issues, good stories, and the Ecomuseum, and he even tried his hand at fly-fishing. His eldest son, Tim, took him on a difficult birding expedition to Trinidad to see Oilbirds (Steatornis caripensis) while he was in a wheel-chair. As his condition worsened, he remained conscious of the effects the disease was having on his body and his mind, ever the curious naturalist, and tried to communicate this to his children.

In the words of his colleague, Gus Mackenzie, "Roger was a unique person with an original approach to life". He was a highly memorable character who left his mark on his science and the projects he fostered. He will be fondly remembered by the interested public, the many students and docents he mentored, and the colleagues he worked with.

\section{Acknowledgments}

All four authors were at one time affiliated with Roger Bider in the Department of Renewable Resources, Macdonald Campus, McGill University. Patrick Weatherhead, Fred Whoriskey, David Rodrigue, Ross MacCulloch, and Raymond Saumure read an earlier draft.

Received 26 June 2013

Accepted 30 October 2013 


\section{Bibliography of Roger Bider}

\section{Scientific and popular publications and technical reports}

Mosimann, J. E., and J. R. Bider. 1960. Variation, sexual dimorphism and maturity in a Quebec population of the common Snapping Turtle, Chelydra serpentina. Canadian Journal of Zoology 38: 19-38.

Bider, J. R. 1961. An ecological study of the Hare, Lepus americanus. Canadian Journal of Zoology 39: 81-103.

Bider, J. R. 1962. Dynamics and the tempero-spatial relations of a vertebrate community. Ecology 43: 634-645.

Bider, J.R. 1966. Parameters of activity at the ground strata of vertebrate communities. Ph.D. thesis accepted as partial fulfillment for the degree of Doctor of Science. Université de Montréal, Montreal, Quebec.

Bider, J. R. 1966. Wildlife on the Farm. Macdonald Farm Journal (February): 9-10.

Bider, J. R. 1968. Aninal activity in uncontrolled terrestrial communities as determined by a sand transect technique. Ecological Monographs 34: 268-308.

Bider, J. R., P. Thibault, and R. Sarrazin. 1968. Schèmes dynamiques spatio-temporels de l'activité de Procyon lotor en relation avec le comportement. Mammalia 2: 1-30.

Pimlott, D. H., J. R. Bider, and R. C. Passmore. 1968. Investigation into the decline of deer in the counties north of Montreal. Report in French and English to l'Honorable C. E. Loubier, Ministre du Tourisme, de la Chasse et de la Pêche. Quebec City, Quebec. 53 pages.

Doucet, G. J., and J. R. Bider. 1969. Activity of Microtus pennsylvanicus related to moon phase and moonlight as revealed by the sand transect technique. Canadian Journal of Zoology 47: 1183-1186.

Baker, B. E., H. W. Cook, J. R. Bider, and A. M. Pearson. 1970. Snowshoe Hare, Lepus americanus milk. I. Gross composition, fatty acid and mineral constitution. Canadian Journal of Zoology 48(6): 1349-1352.

Bider, J. R. 1970. An ecologist's perspective on the pesticide pollution problem. Macdonald Journal (April): 85-87.

Doucet, G. J., and J. R. Bider. 1970. An unusual surge in the activity of Peromyscus maniculatus after an earthquake. Canadian Journal of Zoology 48: 1448-1450.

Swales, D. E., and J. R. Bider. 1970. Nardus stricta L., Moor Matgrass at Lac Carré, Terrebonne County, Quebec. Canadian Field-Naturalist 84: 49-53.

Bider, J. R., and W. Hoek. 1971. An efficient and apparently unbiased sampling technique for population studies of Painted Turtles. Herpetologica 27: 481-484.

Bider, J. R., and J-P. R. Sarrazin. 1971. Spatial utilization, activity, and predation of the shrew Sorex cinereus in central Newfoundland and an evaluation of the 5-day trap census method for estimating population levels. Report to Environment Canada, Forestry Service, St. John's, Newfoundland.

Pimlott, D. H., C. J. Kerswill, and J. R. Bider. 1971. La recherché piscicole et faunique. Science Council of Canada, Étude spéciale no. 15. Information Canada, Ottawa, Ontario. 205 pages.

Pimlott, D. H., C. J. Kerswill, and J. R. Bider. 1971. Scientific activities in fisheries and wildlife resources. Background Study for the Science Council of Canada. Special study No. 15. Information Canada, Ottawa, Ontario.

Bider, J. R. 1972. The Ste-Scholastique International Airport: a study of environmental impact. Blue Jay 30: 209-215.
Bider, J. R. 1972b. Ste. Scholastique: reflections on the grand design. Macdonald Journal 33(11): 3-8.

Bider, J. R., and J-P. R. Sarrazin. 1972. Spatial utilization, activity and predation of the shrew, Sorex sinereus cinereus, in central Newfoundland; and development of a trap census method for estimating population levels. Environment Canada, Forestry Service, St. John's, Newfoundland. Information Report N-X-78.

Bider, J. R., and E. Thompson. 1972. Ecology and management of animal resources. Écologie de la Zone de l'Aéroport International de Montréal. Rapport préliminaire No. 4. Le Centre de recherches écologiques de Montréal, Montreal, Quebec.

Bider, J. R. 1973. Stopping the flight of extinction. Macdonald Journal 34(2): 3-5.

Ouellet, H., and J. R. Bider. 1973. White-crowned Sparrow breeding at Deception Bay, Nouveau Quebec. Canadian Field-Naturalist 87: 321.

Sarrazin, J-P. R., and J. R. Bider. 1973. Activity, a neglected parameter in population estimates - the development of a new technique. Journal of Mammalogy 54: 369-382.

Bider, J. R. 1974. Coyotes and other farm pests. Macdonald Journal 35(11): 3-4.

Bider, J. R. 1974. Ecological determinants of social life and mating patterns in animals. Pages 7-21 in Configurations: Biological and Cultural Factors in Sexuality and Family Life. Edited by R. Prince and D. Barrier. Lexington Books, Lexington, Massachusetts.

Bider, J. R. 1974. Snowshoes in the north woods. Nature Canada 3(1): 20-24.

Bider, J. R., and R. MacCulloch. 1974. The Terrestrial Animal Community, Camp Attila, James Bay Region: An Assay of Animal Activity. For James Bay Energy Corporation, Montreal, Quebec. 203 pages.

Doucet, G. J., and J. R. Bider. 1974. The effects of weather on the activity of the Masked Shrew. Journal of Mammalogy 55: 348-363.

Doucet, G. J., J-P. R. Sarrazin, and J. R. Bider. 1974. Utilization of highway overpass embankments by Woodchuck, Marmota monax. Canadian Field-Naturalist 88: 187-190.

Fitzgerald, G. J., and J. R. Bider. 1974. Evidence of a relationship between age and activity in the toad, Bufo americanus. Canadian Field-Naturalist 88: 499-501.

Fitzgerald, G. J., and J. R. Bider. 1974. Influence of moon phase and weather factors on locomotor activity in Bufo americanus. Oikos 25: 338-340.

Fitzgerald, G. J., and J. R. Bider. 1974. Seasonal activity of the toad, Bufo americanus, in southern Quebec as revealed by a sand transect technique. Canadian Journal of Zoology 52: 1-5.

Stewart, R. W., and J. R. Bider. 1974. Reproduction of ditch-dwelling Muskrats in south Quebec. Canadian FieldNaturalist 88: 429-436.

Bider, J. R. 1974. Rapport au gouvernement du Burundi sur la conservation et gestion de la faune et de la flore au Burundi. No. 3288 of Programme des Nations Unies pour le développement. Food and Agriculture Organization of the United Nations, Rome, Italy.

Bider, J. R. 1975. Forestry practices and their influence on animal communities. Forestry Chronicle 51: 294-296.

Bider, J. R. 1975. Report Number 2 on the Terrestrial Animal Community: Camps Attila, B 160, and Areas West of LG4 between the La Grande and Eastmain Rivers. Impact Eval- 
uation. For James Bay Energy Corporation, Montreal, Quebec.

MacCulloch, R. D., and J. R. Bider. 1975. New records of amphibians and Garter Snakes in the James Bay area of Quebec. Canadian Field-Naturalist 89: 80-82.

MacCulloch, R. D., and J. R. Bider. 1975. Phenology, migrations, circadian rhythm and the effect of precipitation on the activity of Eurycea b. bislineata in Quebec. Herpetologica 31: 433-439.

Bider, J. R. 1976. The distribution and abundance of terrestrial vertebrates of the James and Hudson Bay regions of Quebec. Cahiers de géographie du Québec 20: 393-408.

Bider, J. R., E. R. Thompson, and R. W. Stewart. 1976. Ecology and management of animal resources: écologie de la zone de l'Aéroport International de Montréal. Les Presses de l'Université de Montréal, Montreal, Quebec. xxii, 246 pages.

Bider, J. R., R. D. Titman, and R. G. Clark. 1976. Study of corn crop damage by blackbirds in the Masson area of Quebec. Report in fulfillment of contract no. OSW5-0108. Department of Supply and Services, Ottawa, Ontario.

Wishart, R. A., and J. R. Bider. 1976. Habitat preferences of Woodcock in southwestern Quebec. Canadian FieldNaturalist 91: 141-147.

Stewart, R. W., and J. R. Bider. 1977. Summer activity of Muskrats in relation to weather. Journal of Wildlife Management 41: 487-499.

Bider, J. R., and R. D. Titman. 1978. Blackbird studies at Macdonald College. Macdonald Journal 39(10): 3-5.

Martin, M. L., and J. R. Bider. 1978. A transmitter attachment for blackbirds. Journal of Wildlife Management 42: 683-685.

Vickery, W. L., and J. R. Bider. 1978. The effect of weather on Sorex cinereus activity. Canadian Journal of Zoology 56: 291-297.

Bider, J. R. 1979. Conservation and management of resources dependent on forests: a paper for Biomass Strategy consultation. Pages 29-33 in Canada/Man and Biosphere (MAB) Committee Report No. 12. Canadian Commission for UNESCO.

Bider, J. R. 1979. Évaluation des densités de populations de castor et description des habitats favorables dans le secteur de la Grande Rivière de la Baleine. Hydro-Québec, Environnement, Montreal, Quebec. 22 pages.

Bider, J. R. 1979. Rapport synthèse: évaluation des densités de populations de castors et description des habitats favorables dans le secteur Grande Rivière de la Baleine. Hydro-Québec, Environnement, Montreal, Quebec. 7 pages.

Bider, J. R. 1979. A synthesis of duck studies carried out in the Great Whale and Little Whale basin region from 1975 to 1978. Hydro-Québec, Environnement, Montreal, Quebec.

Bramwell, R. N., and J. R. Bider. 1979. A method for monitoring the terrestrial animal community of a powerline right-of-way. Environmental Concerns in Rights-of-way Management: Proceedings of Second Symposium held October 16-18, 1979, Ann Arbor, Michigan. Edited by R. Tillman. U.S. Fish and Wildlife Service and Electric Power Research Institute, Palo, Alto, California.

Clark, R. G., R. D. Titman, and J. R. Bider. 1979. Attitudes of Canadians toward the control of Red-winged Blackbirds. Pages 235-247 in Proceedings of the Eighth Bird Control Seminar. Edited by W. B. Jackson. Environmental
Studies Center, Bowling Green State University, Bowling Green, Ohio.

Doucet, G. J., and J. R. Bider. 1979. Hydroelectric developments in northern Quebec. Pages 225-234 in Transactions of the 44th North American Wildlife and Natural Resources Conference. Wildlife Management Institute, Washington, D.C.

Weatherhead, P. J., and J. R. Bider. 1979. Management options for blackbird problems in agriculture. Phytoprotection 60: 145-155.

Weatherhead, P. J., J. R. Bider, and R. G. Clark. 1979. On the feasibility of surfactants as a blackbird management tool in Quebec. Proceedings of the Eighth Bird Control Seminar. Edited by W. B. Jackson. Environmental Studies Center, Bowling Green State University, Bowling Green, Ohio.

Bider, J. R., and G. A. Bracher. 1980. Évaluation de la technique du transect de sable dans une étude d'impact suite à une pulvérisation forestière de Matacil. Ministère de l'Energie et des Ressources du Québec.

Burgess, S. A., and J. R. Bider. 1980. Effects of stream habitat improvements on invertebrates, trout populations, and mink activity. Journal of Wildlife Management 44: 871880 .

Weatherhead, P. J., and J. R. Bider. 1980. Avian range extension northward to Deception Bay, Quebec. Arctic 33: 369.

Weatherhead, P. J., J. R. Bider, and R. G. Clark. 1980. Surfactants and the management of Red-winged Blackbirds in Quebec. Phytoprotection 61: 39-47.

Weatherhead, P. J., R. G. Clark, J. R. Bider, and R. D. Titman. 1980. Movements of blackbirds and starlings in southwestern Quebec and eastern Ontario in relation to crop damage and control. Canadian Field-Naturalist 94: 7579.

Weatherhead, P. J., H. Greenwood, S. H. Tinker, and J. R. Bider. 1980. Decoy traps and the control of blackbird populations. Phytoprotection 61: 65-71.

Bider, J. R., and K. A. Morrison. 1981. Changes in Toad, Bufo americanus, responses to abiotic factors at the northern limit of their distribution. American Midland Naturalist 106: 293-304.

Vickery, W. L., and J. R. Bider. 1981. The influence of weather on rodent activity. Journal of Mammalogy 62: $140-145$.

Bracher, R. G., and J. R. Bider. 1982. Changes in terrestrial animal activity of a forest community after an application of aminocarb (Matacil). Canadian Journal Zoology 60: 1981-1997.

Clark, R. G., R. D. Titman, J. R. Bider, and M. Prévost. 1982. Aspects of the socioeconomic impact of blackbirds and other vertebrates on farm production in Quebec. Phytoprotection 63: 56-67.

Doucet, G. J., and J. R. Bider. 1982. Changes in animal activity immediately following the experimental clearing of a forested right-of-way. Pages 592-601 in Proceedings of the Third International Symposium on Environmental Concerns in Rights-of-Way Management, February 15-18, 1982, San Diego, California. Edited by A. F. Crabtree. Mississippi State University, Starkville, Mississippi.

Bider, J. R., and D. M. Bird. 1983. Distribution and densities of osprey populations in the Great Whale region of Quebec. Pages 223-230 in Biology and Management of Bald Eagles and Ospreys: Proceedings of the 1st International 
Symposium on Bald Eagles and Ospreys, Montréal, 28-29 October, 1981. Edited by D. M. Bird. Macdonald Raptor Research Centre, McGill University, Sainte-Anne-deBellevue, Quebec. 325 pages.

Bider, J. R., and P. G. Weil. 1984. Dog, Canis familiaris, killed by a Coyote, Canis latrans, on Montreal Island, Quebec. Canadian Field-Naturalist 98: 498-499.

Doucet, G. J., J. R. Bider, P. Lamothe, and D. T. Brown. 1984. Wildlife data issues in the routing of energy corridors. Pages 491-506 in Facility Siting and Routing 84: Energy and Environment: Proceedings of a Symposium held at Banff, Alberta, Canada, April 15-18, 1984 (Volume 2). Environmental Protection Service, Environment Canada.

Flaherty, N., and J. R. Bider. 1984. Physical structures and the social factor as determinants of habitat use by Graptemys geographica in southwestern Quebec. American Midland Naturalist 111: 259-262.

Bider, J. R. 1985. Évaluation de la clé de potentiel élaboré sur le rat musqué dans le cadre du projet Archipel. Ministère du Loisir, de la Chasse et de la Pêche, Parc Archipel, Montreal, Quebec.

Gascon, C., and J. R. Bider. 1985. The effect of $\mathrm{pH}$ on Bullfrog, Rana catesbiana, and Green Frog, Rana clamitans melanota, tadpoles. Canadian Field-Naturalist 99: 259-261.

Bracher, G. A., P. D. Kingsbury, and J. R. Bider. 1986. A comparison of two techniques for assessing the impact of pesticides on small animals. Canadian Field-Naturalist 100: 52-57.

Christens, E., and J. R. Bider. 1986. Reproductive ecology of the Painted Turtle (Chrysemys picta marginata) in southwestern Quebec. Canadian Journal of Zoology 64: 914 920.

Brunelle, J., and J. R. Bider. 1987. Étude de la population de castors (Castor canadensis) de la réserve faunique des Laurentides, Québec: rapport final. Direction de la Gestion des espèces et des habitats, Ministère du Loisir, de la Chasse et de la Pêche, Québec. 70 pages.

Christens, E., and J. R. Bider. 1987. Nesting activity and hatchling success of the Painted Turtle (Chrysemys picta). Herpetologica 43: 55-65.

Gauthier, R., and J. R. Bider. 1987. The effects of weather on runway use by rodents. Canadian Journal of Zoology 65: 2035-2038.

Bider, J. R., and S. Matte. 1988. Atlas des amphibiens et des reptiles du Québec. Société d'histoire naturelle de la Vallée du Saint-Laurent, Sainte-Anne-de-Bellevue, Quebec., and Ministère du Loisir, de la Chasse et de la Pêche. 279 pages.

Robinson, C., and J. R. Bider. 1988. Nesting synchrony as a reproductive strategy of the Snapping Turtle (Chelydra serpentina). Journal of Herpetology 22: 470-473.

Bider, J. R., and S. Matte. 1989. Atlas des amphibiens et des reptiles du Québec. Ministère du Loisir, de la Chasse et de la Pêche, Québec. 355 pages.

Bider, J. R. 1990. Wildlife in Stanbridge Township: a centennial publication of the Historical Society of Stanbridge.

Bider, J. R., and S. Matte. 1990. Atlas des amphibiens et des reptiles du Québec 1988-89. Société d'histoire naturelle de la Vallée du Saint-Laurent, Sainte-Anne-de-Bellevue, Québec, and Ministère du Loisir, de la Chasse et de la Pêche, Direction de la Gestion des Espèces et des Habitats, Service des études écologiques, Québec, Québec. 355 pages.

Bider, J. R. 1991. A walk through the Ecomuseum and 1'Ecotour: a walking guide to the exhibits of the Ecomuseum.
Second edition. Saint Lawrence Valley Natural History Society, 1993.

Bider, J. R., and S. Matte. 1991. Atlas des amphibiens et des reptiles du Québec. Ministère du Loisir, de la Chasse et de la Pêche, Québec. 429 pages.

Bider, R., S. Matte, and J. Bonin. 1991. Conservation des sites à haut potentiel herpétofaunique de l'Île Perrot. Fondation de la Faune et Service canadien de la faune, Environnement Canada, Québec. 21 pages +5 annexes.

Bider, J. R. 1992. The Mouflon of Cyprus, estimates of numbers and recommendations regarding their management. Commonwealth Secretariat, London, and the Department of Game and Fauna, Cyprus.

Hadjisterkotis, E., and J. R. Bider. 1992. Dog predation on Cyprus Mouflon. Caprinae News 6: 17-20.

Hadjisterkotis, E., and J. R. Bider. 1993. Reproduction of the Cyprus Mouflon, Ovis gmelini ophion, in captivity and in the wild. International Zoo Year Book 32: 125-132.

Bider, J. R., and S. Matte. 1994. Atlas des amphibiens et des reptiles du Québec. Société d'histoire naturelle de la vallée du Saint-Laurent and Ministère de l'Environnement et de la Faune. Direction de la faune et des habitats, Québec. 106 pages.

Bider, J. R., and S. Matte. 1996. The atlas of amphibians and reptiles of Quebec. St. Lawrence Valley Natural History Society, Sainte-Anne-de-Bellevue, and Ministère de l'Environnement et de la Faune. Direction de la faune et des habitats, Québec. 106 pages.

Saumure, R. A., and J. R. Bider. 1996. Clemmys insculpta (Wood Turtle) ectoparasites. Herpetological Review 27: 197-198.

Hadjisterkotis, E., and J. R. Bider. 1997. Cyprus. Pages 8992 in Wild Sheep and Goats and Their Relatives: Status Survey and Conservation Action Plan for Caprinae. Edited by D. M. Shackleton. IUCN/SSC (Species Survival Commission) Caprinae Specialist Group. IUCN, Gland, Switzerland.

Saumure, R. A., and J. R. Bider. 1998. Impact of agricultural development on a population of Wood Turtles (Clemmys insculpta) in southern Quebec, Canada. Chelonian Conservation and Biology 3: 37-45.

\section{Theses supervised:}

Thibault, J. P. 1968. L'activité animale près d'un ruisseau situé en forêt. M.Sc. thesis, McGill University, Montreal, Quebec.

Côté, Y. 1969. Étude écologique de l'omble de fontaine, Salvelinus fontinalis (Mitchell), d'un ruisseau des Laurentides. M.Sc. thesis, McGill University, Montreal, Quebec.

Pellerin, L. 1969. Activité phénologique et dynamique de l'utilisation de l'aire d'une population de Napaeozapus insignis. M.Sc. thesis, McGill University, Montreal, Quebec.

Sarrazin, J-P. R. 1969. L'activité, un parameter négligé, dans l'estimation de population : développement d'une nouvelle technique. M.Sc. thesis, McGill University, Montreal, Quebec.

Vernier, D. 1969. Phénologie de l'activité et comportement du lièvre d'Amérique, Lepus americanus, face aux appâts et au pièges. M.Sc. thesis, McGill University, Montreal, Quebec.

Weary, G. C. 1969. An ecological study of snakes in the Quebec Laurentians. M.Sc. thesis, McGill University, Montreal, Quebec. 
Doucet, G. J. 1970. The effect of selected weather factors on the daily activity of the Masked Shrew, Sorex cinereus cinereus (Kerr) in an uncontrolled environment. M.Sc. thesis, McGill University, Montreal, Quebec.

Gauthier, M. C. 1971. The activity of the Striped Skunk, Mephitis mephitis (Schreber), in Quebec. M.Sc. thesis, McGill University, Montreal, Quebec.

Fitzgerald, G. 1972. Several aspects of the behavior of the toad, Bufo americanus in Quebec. M.Sc. thesis, McGill University, Montreal, Quebec.

Inhaber, J. 1972. Behavior and attitudes of suburban forest recreationists in the Morgan Arboretum, Quebec. M.Sc. thesis, McGill University, Montreal, Quebec.

Vickery, W. L. 1973. The effect of weather, predation and competition on Sorex cinereus activity: an empirical model. M.Sc. thesis, McGill University, Montreal, Quebec.

Wishart, R. A. 1973. The behavior and habitat requirements of the American Woodcock in Quebec. M.Sc. thesis, McGill University, Montreal, Quebec.

Bailey, R. O. 1974. Some aspects of wild Mallard stocking on a large marsh habitat. M.Sc. thesis, McGill University, Montreal, Quebec.

Stewart, R. W. 1974. Reproduction and survival of ditchdwelling Muskrats in southern Quebec. M.Sc. thesis, McGill University, Montreal, Quebec.

Bird, D. M. 1975. Artificial insemination and semen production of the American Kestrel. M.Sc. thesis, McGill University, Montreal, Quebec.

Doucet, G. J. 1975. Effect of habitat manipulation on the activity of an animal community. Ph.D. thesis, McGill University, Montreal, Quebec.

Thompson, E. R. 1975. An evaluation of parameters used to map wildlife resources. M.Sc. thesis, McGill University, Montreal, Quebec.

Mallet, H. 1976. Activité, croissance et tables de survie d'une population de tortues peintes, Chrysemys picta, du sud du Québec. M.Sc. thesis, McGill University, Montreal, Quebec.

O'Neil, J. K. 1976. The application of a tracking-trapping technique for population estimates. M.Sc. thesis, McGill University, Montreal, Quebec.

Vickery, W. L. 1976. Activity and feeding behavior of three sympatric species of forest mice. Ph.D. thesis, McGill University, Montreal, Quebec.

Martin, M. L. 1977. Summer movements of blackbirds damaging corn. M.Sc. thesis, McGill University, Montreal, Quebec.

Burgess, S. A. 1978. Aspects of Mink, Mustela vison, ecology in the southern Laurentians of Quebec. M.Sc. thesis, McGill University, Montreal, Quebec.

Bramwell, R. N. 1980. Animal activity, weather and vegetation control along a Quebec powerline right-of-way. M.Sc. thesis, McGill University, Montreal, Quebec.

Ramsay, T. J. 1980. Snowshoe Hare browse in northwest Quebec: an estimation of its nutrient composition. M.Sc. thesis, McGill University, Montreal, Quebec.

Bracher, G. A. 1981. The impact of aminocarb on the activity of a terrestrial animal community. M.Sc. thesis, McGill University, Montreal, Quebec.
Phaneuf, J. 1981. Étude socio-écologique de l'Étang de Miragoane, Haiti. M.Sc. thesis, McGill University, Montreal, Quebec.

Belanger, R. 1982. The influence of rain on the behavior of Muskrats (Ondatra zibethicus), other small mammals and their predators. M.Sc. thesis, McGill University, Montreal, Quebec.

Flaherty, N. C. 1982. Home range, movement and habitat selection in a population of Map Turtle, Graptemys geographica (Le Sueur), in southwestern Quebec. M.Sc. thesis, McGill University, Montreal, Quebec.

Morrison, K. A. 1983. Environmental factors influencing toad activity at different locations in Quebec. M.Sc. thesis, McGill University, Montreal, Quebec.

Christens, E. 1985. Nesting ecology and hatching success of the Painted Turtle (Chrysemys picta marginata) in southwestern Quebec. M.Sc. thesis, McGill University, Montreal, Quebec.

Gauthier, R. 1986. A method of quantifying variations in runway utilization by five species of rodents. M.Sc. thesis, McGill University, Montreal, Quebec.

Olpinski, S. 1986. Reproduction of Rock Ptarmigan in Nouveau-Quebec. M.Sc. thesis, McGill University, Montreal, Quebec.

Tanguay, G. 1986. Diurnal activity and behavior patterns of captive ditch-dwelling Muskrats. M.Sc. thesis, McGill University, Montreal, Quebec.

Brunelle, J. 1987. Characteristics of two adjacent Beaver (Castor canadensis) populations in Quebec. M.Sc. thesis, McGill University, Montreal, Quebec.

Delorme, L. 1988. Interspecific interactions of Raccoons (Procyon lotor) at a feeding station. M.Sc. thesis, McGill University, Montreal, Quebec.

Robinson, C. 1989. Orientation and survival of hatchlings and reproductive ecology of the common Snapping Turtle (Chelydra serpentina) in southern Quebec. M.Sc. thesis, McGill University, Montreal, Quebec.

Bonin, J. 1992. Effect of forest age on woodland amphibians and the habitat and status of stream salamanders in southwestern Quebec. M.Sc. thesis, McGill University, Montreal, Quebec.

Hadjisterkotis, E. 1993. Ecology and management of the Cyprus Mouflon. Ph.D. thesis, McGill University, Montreal, Quebec.

Nadeau, S. 1995. Muskrat habitat use in Quebec. Ph.D. thesis, McGill University, Montreal, Quebec.

Galois, P. 1996. Turtle nest sensory perception by Raccoon (Procyon lotor) and Striped Skunk (Mephitis mephitis): an approach through discrimination learning of potential nest cues. Ph.D. thesis, McGill University, Montreal, Quebec.

Saumure, R. 1997. Growth, mutilation and age structure of two populations of Wood Turtle (Clemmys insculpta) in southern Quebec. M.Sc. thesis, McGill University, Montreal, Quebec.

Walde, A. 1998. Ecology of the Wood Turtle (Clemmys insculpta), Québec, Canada. M.Sc. thesis, McGill University, Montreal, Quebec. 